\title{
Career Pathing Among General Administrative And Support Services Employees Based On Holland's Typology Of Personality Theory And Personal Style Inventory
}

Catalino N. Mendoza, University of Batangas, Philippines

\begin{abstract}
The study is about the prevailing differences, commonalities and significant contributions of the career pathing among the general administrative and support services employees based on Holland's Typology of Personality Theory and Personal Style Inventory of selected higher educational institutions in Metro Manila.
\end{abstract}

Keywords: career pathing in the Philippines and career pathing for the general administrative and support services in the Philippines

\section{INTRODUCTION}

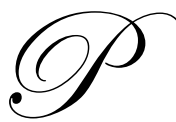

eople generally go to work to do a good job. However, it is not always the good company that every person aims for or dreamed of after graduation that matters, but the position and the satisfaction that the company or job can offer. Thus, a person needs to be recognized for whatever contribution/s one has given as a measure of one's worth to the company. Satisfaction happens when a person's contribution has been recognized in terms of talents, skills and attitudes that helped toward the realization of the company's vision, mission, and objectives, as well as one's vision, mission, and goals in life.

An organization owes itself the ability to get as much from the minds of its people as it possibly can. Developing an employee and providing a path that leads to higher performance and individual development spells the difference between organizational success and failure. (IRI Consultants to Management, Inc.)

It is also a firm belief that higher educational institutions, like any organization, have their own Human Resource Management department, whose main function is to extract the best and to develop effective and efficient human resources in the organization. Aside from considering human resource management as a challenging work that focuses on issues, problems, and principles involved in the management of people at work, which are common to all organization, it is also noteworthy that these processes and practices should be given effective and efficient implementation of career pathing or career development programs. It is undeniable that organizations exist because of people. People are the most important and essential factor for growth and progress of an organization. Through men, the seven "Ms" of a company - manpower, money, materials, methods, markets, machines, and minutes - are utilized.

On the one hand, the aim and challenge of having and creating competent managing organizations come from people-related problems that are often caused by the mistaken belief that people are alike. Cascio (1995) puts it, "no two people are exactly alike, and everyone differs physically and psychologically from everyone else. On the other hand, these differences demand attention so that each person can maximize his/her potential in order for 
organizations to maximize their effectiveness and that society, as a whole, can make the wisest use of its human resource." Thus, in an organization, each employee has a role to play in management of the company.

The organization indeed has a great concern for its employees' performance. That is why an organization implements the effective practice of managing human resources for employees to do well in their jobs. How these organizations implement and assess their career pathing or career development program is the main concern of this study. Effective and efficient implementation of their practices on career pathing and career development will surely lead to the attainment of both individual and organizational goals.

Similar studies have already been undertaken in the past, most notably in other countries where there is greater awareness and interest for career pathing and career management.

The study entitled: "Motivational Drivers Affecting Career Choices in the Resource Sector", by Dan Churach and Tony Rickards of Australia, was presented at the Fourth International Conference on Science Mathematics and Technology Education (2005) in Canada (Uchida, 2006).

In that study, the authors came upon some unexpected results, with the respondents (professionals in the mineral and energy resource sector) choosing four other factors (among a total of six) as the chief motivators or influencers in their career path decision. The results raised quite a few eyebrows, especially as it is a common belief that monetary reward is the main element considered by workers.

To that end, the researcher became interested in the study to satisfy his eagerness to know the following:

1. the profile of the general administrative and support services employees using the John Holland's Typology of Personality

2. the profile of the general administrative and support services employees using the Personal Style Inventory, as defined by Dr. R. Craig Hogan and Dr. David W. Champagne

3. the predictors in Holland's Topology of Personality among the general administrative and support services employees in selected higher educational institutions in metro Manila

4. the predictors in Personal Style Inventory, as defined by Dr. R. Craig Hogan and Dr. David W. Champagne, among the general administrative and support service employees in selected higher educational institutions in metro Manila

5. the significant differences on the personality of the general administrative and support services employees in selected tertiary educational institutions in metro Manila based on Holland's Typology of Personality

6. the significant differences on the personality of the general administrative and support services employees in selected higher educational institutions in metro Manila based on Personal Style Inventory, as defined by Dr. R. Craig Hogan and Dr. David W. Champagne

7. the significant relationships between the Holland's Typology of Personality and the Hogan and Champagne's Personality Style Inventory

8. the career intervention needed to satisfy the career paths of the general administrative and support services employees in selected tertiary educational institutions

\section{THEORETICAL FRAMEWORK}

According to Young (2006), people go through life with their own career plans. To have a career is to engage in a series of job tasks essential for professional growth in one's occupational life. Career refers to the sequence of activities and jobs engaged in by an individual during his work life.

The theoretical framework of this study is anchored on Holland's Topology. This theory discusses different occupational orientations. Individuals are unique and consequently have different tendencies and inclinations. 


\section{JOHN HOLLAND'S TYPOLOGY OF PERSONALITY AND SAMPLE OCCUPATIONS}

Career paths can also be seen in perspective of the personal interests and inclinations of individuals. Hence, using the Typology of Personality and Sample Occupations by J. L. Holland (1959), occupational choices arise from six basic personality types.

All six (6) career preference classifications are unique, though cross-over personalities are possible.

Holland defines each personality type (www.salisbury.edu, 2006) as follows: (1) Realistic (R type) - this type usually has mechanical and athletic abilities, enjoys working outdoors and likes to work with tools and machines. The R-type generally prefers to work with ideas more than people or things; (2) Investigative (I type) this type usually has mathematical and scientific abilities, enjoys working alone and likes to solve problems. The type I generally favors working with ideas more than with people or things; (3) Artistic (A type) - this type has artistic skills, enjoys creating original work and has a good imagination. The A type usually enjoys working with ideas more than things; (4) Social (S type) - this type usually has social skills, is interested in human relationships and likes to help others with problems. The $S$ type likes to work with people more than things; (5) Enterprising (E type) - usually has leadership and speaking abilities, is interested in economics and politics and likes to be influential. The $\mathrm{E}$ type likes to work with people and ideas more than things; and (6) Conventional (C type) - this type has clerical and arithmetic ability, prefers working indoors and likes to organize things. The $\mathrm{C}$ type enjoys working with words and numbers.

Holland talks about 'congruence' between a person and his environment saying that individuals seek into themselves in an attempt to find out who they are.

In this process, the individual realizes what his/her interests are and where his/her inclination lies. "Thus, congruence refers to the extent that someone has the same personality type as the environment in which he or she is working," Holland says. Some researches have learned that "high congruence leads to better performance, satisfaction, and length of time in a career."

In fact, it is aptly said that human resource management is the most important asset in an organization, no less than the late President Ferdinand E. Marcos has underscored the importance of human resources. In his keynote speech before the seminar workshop on Human Resource Development on July 24, 1978, he said:

If today there is much talk of harnessing human resources for development and nation building in our part in the world, it is perhaps a reflection of the times of change and challenge that have visited the world in our time. It is the mirror of urgency of the development, and all that we have come to recognize to be the circumstances and capacities for our developing societies, have led us irrevocably to the appreciation of the potentials of our human resources.

Leading others in the pursuit of organizational objectives is one of the most challenging roles of management, and motivating people to achieve preferred results is a crucial part of that leadership role. Motivation seems inextricably related to organizational performance; people are convinced that highly motivated individuals working "smarter" are more productive, both quantitatively and qualitatively. Thus, productivity is achieved by having an organization of highly motivated individuals. Motivation is the concept of behavioral change or results in influence that alters an individual's performance.

In broad terms, motivation is the stimulus of behavior. It is the composite of energetic forces that originate within a person and that are stimulated by his or her surroundings to initiate behavior. Managers need to know how people are motivated and what stimulates their behavior so they can determine its form, direction, intensity, and duration.

Theorists approach motivation from three general perspectives: 1) Content theory focuses on human needs or desires that are internalized and give impetus to individual behavior, 2) Process theory examines employee behavior in terms of job satisfaction related to perceived rewards (or lack of rewards) that instigate behavior, and 3) 
Reinforcement theory is based on the concept of operant conditioning in which individuals, having learned from the past, develop patterns of behavior to control future consequences.

Understanding motivation consists largely of recognizing patterns of needs and then encouraging behavior which results in satisfying them. The crucial characteristic of content theory is that unmet or deprived needs result in a state of tension that motivates individuals to act in order to satisfy the deprivation. Motivation, however, is not simple. Both physiological and psychological needs are multifaceted concepts confounded by individual values. People's value systems vary tremendously.

Another factor affecting motivation is change in individual needs. What motivates an individual one day may have little meaning the next. Hunger may impel people to work, even at the most unpleasant jobs; but once it is satisfied, they need a different reason to continue their job. They will work hard one day and do little the next, and as they grow and their social priorities change, so will their attitudes toward work and rewards (Santos, 1999).

\section{HOGAN AND CHAMPAGNE'S PERSONAL STYLE INVENTORY}

Hogan and Champagne's revolutionary personality test dubbed the Personal Style Inventory (1980) defines an individual's relative strength and weakness in four pairs of personality classifications.

Whereas: the pair of introversion/extroversion corresponds to being someone who prefers to be alone and thinks deeply, or someone who is outgoing and lively, respectively; the pair of intuition/sensing corresponds to being someone who uses gut-feel to make decisions, or someone who requires evidence (tangible characteristics), respectively; the pair of thinking/feeling corresponds to being someone who is more in touch with intellect, or someone more in touch with his/her emotion, respectively; the pair of perceiving/judging corresponds to being someone who looks beyond a given situation, or someone who takes something in its face value.

Usually, any given person will have a dominant trait for each of the four (4) classifications but balanced traits can and will occur.

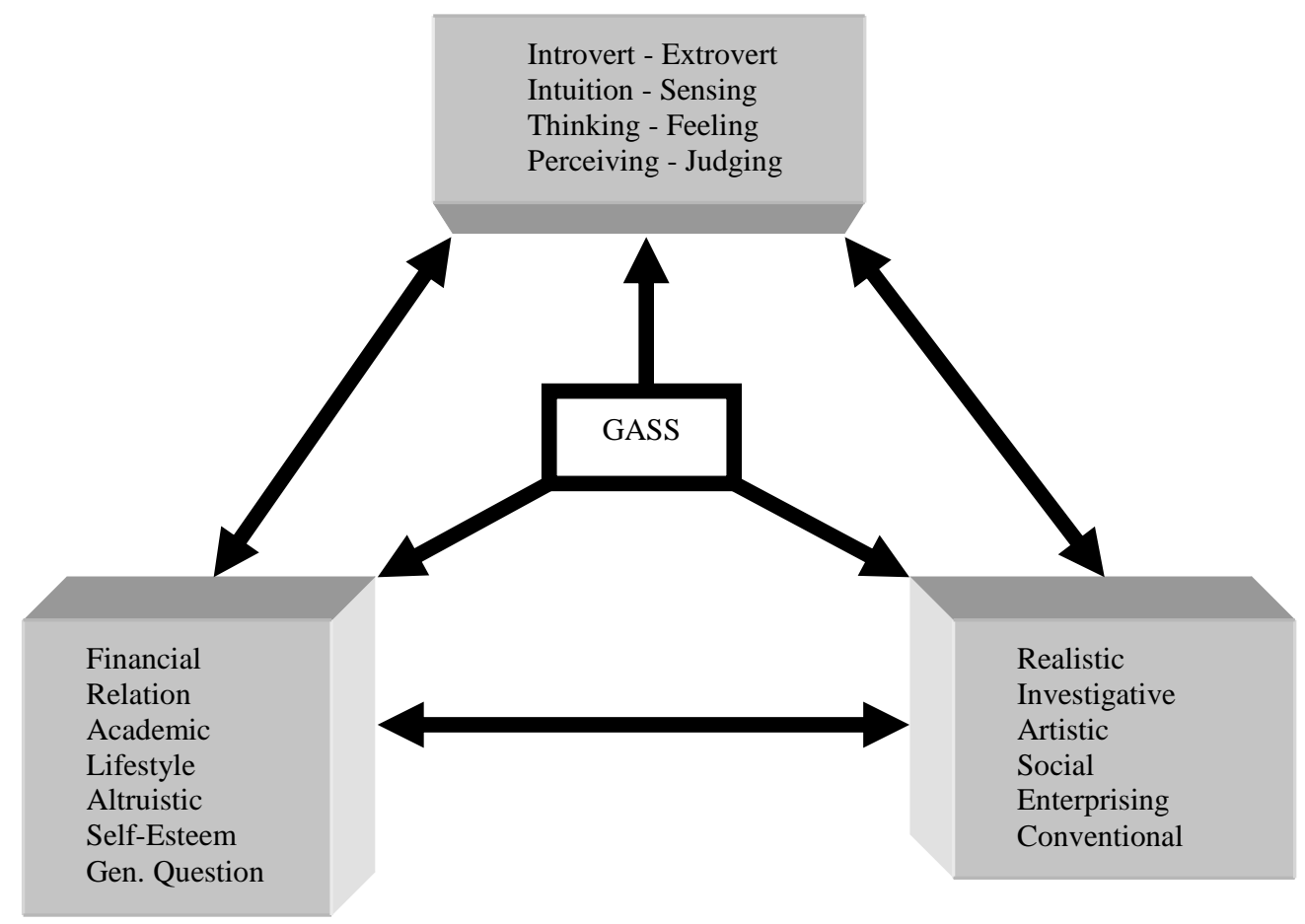

Figure 1

GASS on Holland's Typology and Personal Style Inventory 


\section{THE PARADIGM OF THE STUDY}

The paradigm of the study in Figure 1 shows how the GASS choose their careers based on Holland's Typology of Personality and Occupational Orientation and shows as well how John Holland's Typology is related to the personality of the GASS in selected higher educational institutions in Metro Manila.

It likewise discusses the relationships of the Holland's Typology of Personality and the Personal Style Inventory on the personality of the GASS as well as possible predictors from both theories on the career pathing of the GASS in selected higher educational institutions in Metro Manila.

\section{STATEMENT OF THE PROBLEM}

This research attempted to present the prevailing career pathing among the General Administrative and Support Services Personnel Based on Holland's Typology of Personality in Selected Higher Educational Institutions in Metro Manila.

Specifically, the research sought to answers the following questions,

1. What are the profiles of the general administrative and support services employees in terms of:

a. Gender and

b. Civil status

2. What are the profiles of the general administrative and support services employees using the John Holland's Typology of Personality?

3. What are the profiles of the general administrative and support services employees according to their career choice?

4. What are the profiles of the general administrative and support services employees using the Personal Style Inventory defined by Dr. R. Craig Hogan and Dr. David W. Champagne?

5. Are there predictors in Holland's Topology of Personality among the general administrative and support services employees in Selected Higher Educational Institutions in Metro Manila?

6. Are there predictors in Personal Style Inventory defined by Dr. R. Craig Hogan and Dr. David W. Champagne among the general administrative and support services employees in Selected Higher Educational Institutions in Metro Manila?

7. Is there a significant difference on the personality of the general administrative and support services employees in Selected Higher Educational Institutions in Metro Manila based on Holland's Typology of Personality?

8. Is there a significant difference on the personality of the general administrative and support services employees in Selected Higher Educational Institutions in Metro Manila based on Personal Style Inventory as defined by Dr. R. Craig Hogan and Dr. David W. Champagne?

9. Is there a relationship between Holland's Typology of Personality and the Hogan and Champagne's Personality Style Inventory?

\section{RESEARCH METHOD}

This research used a combination of descriptive and correlation researches.

Descriptive research is that which endeavors to describe systematically, factually, accurately, and objectively a situation, problem, or phenomenon. characteristics.

Correlation research tries to probe the significance of the relationship between two or more factors or

The study determined the three profiles namely: the demographic profile, the typology of personality profile and the personal style inventory profile. 
After describing the profiles of the general administrative and support services employees using the three instruments and the results of the Career Profile Inventory test, correlation and regression analysis were applied to test for influence and impact.

\section{RESEARCH LOCALE}

The selected higher educational institutions in Metro Manila are as follows: Eulogio "Amang" Rodriguez Institute of Science and Technology (EARIST), Philippine Normal University (PNU), Rizal Technological University (RTU), Technological University of the Philippines (TUP), Manuel Luis Quezon University (MLQU), Philippine Christian University Manila (PCU), and St. Paul University Manila (SPUM, St. Paul University System).

\section{POPULATION AND SAMPLING TECHNIQUES}

The research used a stratified random sampling method to determine the sample size with a total of 280 general administrative and support services employees as respondents from seven (7) different higher educational institutions in Metro Manila.

Respondents are assigned in different departments such as Accounting, Personnel or Human Resource, Clinic, Registrar, Canteen, Administrations, Engineering, Facility, and other offices.

Respondents whose works are from clerks to supervisors are also receiving salaries between a minimum of Three hundred pesos a day (P350/day) to a maximum of One thousand pesos a day (P1000).

\section{RESEARCH INSTRUMENT USED}

Three research instruments were used in this study. The first is called the Career Profile Inventory (CPI) which is an adaptation of the Science Career Inventory ( $\mathrm{SCI}$ ) used by researchers Churach and Rickards in an Australian industry endorsed by the Fourth International Conference on Science, Mathematics and Technology Education.

The CPI, aside from the usual template questions corresponding to rank and file employees' gender and civil status, will measure the general administrative and support services' choices of the factors that influenced their career path decision. The CPI is broken down into seven sub-factors, namely: Financial, Relationship, Academics, Lifestyle, Altruistic, Personal Esteem, and General.

The CPI has a total of fifty (50) questions divided into seven (7) sub-factors. The sub-factors have six (6) questions except for the general sub-factor which has fourteen (14) questions.

The Five-point Likert Scale was used, five (5) being the highest and one (1) the lowest. The following is the full description of the Five-point Likert Scale. Five (5) for very high influence, 4 for moderately influence, 3 for low influence and 1 for very low influence or none at all.

The second research instrument used is the John Holland Typology of Personality Test which measures the rank and file employees' preference on career work types. The test is available as freeware in the internet.

The test has thirty-six (36) questions divided into six classifications, namely: Realistic, Investigative, Artistic, Social, Enterprising, and Conventional. The scale that will be used is also that of the Five-Point Likert Scale.

To get the sub-test means, the number of items in the sub-test is divided by the sum of the item means. The following norms are then used in the interpretation of data: Outstanding (4.51 - 5.00), Very Satisfactory (3.51 $4.50)$, Satisfactory $(2.51-3.50)$, Unsatisfactory $(1.51-2.50)$, and Poor $(1.00-1.50)$. 
The third test is the Personal Style Inventory which is a yardstick for determining the personality profile of the general administrative and support services employees. The test has thirty-two (32) pairs of questions wherein a general administrative and support service employee had to choose which of the given statement he/she relates to the most by giving a score of zero to five (0-5), with five (5) as the highest, and with each pair of question needing to give a total of five (5) but with the restriction that no fractions (i.g, 2.5) can be given as a score.

The following dimensions measure or determine the personality of the general administrative and support services employees in selected higher educational institutions in Metro Manila that follow the different scoring, pairing and the interpretation of the answers. These are the following: Introversion, Extroversion, Intuition, Sensing, Thinking, Feeling, Perceiving, and Judging interpreted as follows: (20-21) balance in strengths of dimension, (2224) have some strength in one aspect of the dimension and some weakness in the other member of the pair, (25-29) have a definite strength in one aspect of the dimension and definite weakness in the other member of the pair, and (30 -40) have considerable strength in one aspect of the dimension and considerable weakness in the other member of the pair.

\section{PROCEDURE IN GATHERING DATA}

The research instruments were distributed in various ways to selected higher educational institutions in Metro Manila, the personal approach and identifying the appropriate person who could help the researcher in the distribution and retrieval of the questionnaires were used

The researcher also sought permission from Selected Higher Educational Institutions to administer the questionnaire to the respondents. He utilized unstructured questionnaire to determine the veracity of the information and responses given by the identified group of respondents.

\section{STATISTICAL TOOLS USED}

The statistical tools applied and used for the data collected from the study are the percentage, weighted mean, one-way ANOVA and the multiple dummy stepwise regression analysis using backward elimination. All statistical tools were derived from the PH-stat program.

\section{SUMMARY FINDINGS}

Based on the data gathered, the findings are:

1. Most of the general administrative and support services employees are single males with a 57.86 percent contribution to the total population.

2. The general classification of the general administrative and support services employees are artistic, social, and enterprising, while they were characterized by the financial sub-factor of the Career Profile Inventory.

3. The dominant traits of the general administrative and support services employees for the public higher educational institutions are introversion, intuition, feeling and perceiving, while on the private higher educational institutions are extroversion, sensing, feeling, and perceiving. Introversion of the Personality Style Inventory, which is considered as the most prevalent among the general administrative and support service employees.

In comparison from the mean, the public higher educational institutions have employees who are introverts and intuitive while the private higher educational institutions have employees who are extroverts and sensitive. Both the public and the private higher educational institutions have dominant feeling and perceiving traits.

The regression analysis shows that gender has a significant impact on lifestyle and civil status on academic, relationship, and financial factors It also shows that gender and civil status have empirically contributed in affecting the lifestyle and general questions while affecting altruism. The multiple regression analyses show that lifestyle and general questions affect intuition while the general question affect thinking and relation to judging. 
In general, gender and civil status do not affect the career choices of the general administrative and support services employees.

4. There is no significant difference among the different public higher educational institutions, while in the private higher educational institutions, there is a significant difference in terms of Holland's factors.

5. The ANOVA results show that there is a significant difference among the public and private higher educational institutions in Metro Manila in terms of their (the GASS) responses on how personal factors affect their current status.

\section{CONCLUSIONS}

Based on the findings, the following are concluded:

1. Most of the general administrative and support services employees are single males and they are classified as artistic, social, and enterprising. They were also characterized by financial sub-factor of the Career Profile Inventory.

2. The dominant traits of the general administrative and support services employees for the public higher educational institutions are introversion, intuition, feeling and perceiving, while on the private higher educational institutions, they are extroversion, sensing, feeling, and perceiving. Introversion of the Personality Style Inventory is considered the most prevalent. Furthermore, the GASS in the public higher educational institutions are more introverts and intuitive while the private higher educational institutions are more extroverts and sensing. In general, both public and private higher educational institutions have dominant feeling and perceiving traits.

3. Gender has a significant impact on the lifestyle and civil status of academic, relationship, and financial aspects. It also shows that gender and civil status have empirically contributed to affecting the lifestyle and general questions while affecting altruism. It also shows that lifestyle and general questions affect intuition, while the general question affects thinking, relation to judging and gender affecting judging.

4. There is no significant difference among the different public and private higher educational institutions in metro Manila in terms of Holland's factors.

5. There is a significant difference among the public and private higher educational institutions in metro Manila in terms of their (the GASS) responses on how personal factors affect their current status.

\section{RECOMMENDATIONS}

Based on the results of the study, the following are recommended:

1. Strengthen the existing career management program in order for the present general administrative and support services employees to be more effective in their chosen careers.

2. Periodic psychological examinations, career-orientations, and personality aptitude examinations should be given to all general administrative and support services employees, in both private and public higher educational institutions, to update, upgrade and boost their morale, attitudes and awareness.

3. Sub-factor Lifestyle, the career classification Enterprising and the personality classification, Extroversion (those consistent in Regression and ANOVA analysis) should be emphasized by the Human Resource Management people involved in the career management programs as these factors are of utmost significance to career paths.

4. That all institutions should create a career center for their general administrative and support services employees to guide them in their future career choices.

5. Job satisfaction surveys should be distributed to all general administrative and support services employees to find out any dissatisfaction and at the same time to serve as foundation for creating well designed career management programs.

6. The different Higher Educational Institutions in the Philippines should conduct research in relation to the satisfaction of the general administrative and support services employees not only in Metro Manila but also in all parts of the Philippines in order to provide a venue for the development of their employees' careers and to create standard policies that can be applied to all higher educational institutions for the development of well rounded and career-oriented employees. The present study actually evaluated the career pathing of the general administrative and support services employees in selected higher educational institutions in 
Metro Manila. It is therefore strongly recommended that a replication of the present research be conducted using other locale and period for more reliable effects of the method used.

7. It is further recommended that the Career Development Interventions as appended in this manuscript be considered by the Higher Educational Institutions involved in the study as inputs to the career path seminar-workshop, strategic management programs, and other staff development projects.

8. Also, the researcher recommends that a respondent method of research instrument administration be implemented so as to avoid them from being overwhelmed by the amount of survey questions.

9. Other research writers may conduct a research proposal on the correlation of the present careers based on Holland's Typology and other demographic profile of the general administrative and support service employees not only in selected higher educational institutions in Metro Manila but also in the entire country

\section{AUTHOR INFORMATION}

Dr. Catalino N. Mendoza has been in the academe for the last 15 years. An academic consultant, module designer and developer, writer, professor/lecturer and thesis and dissertation consultant, he has to his credit two doctoral degrees-Doctor of Management Science and Doctor of Philosophy in Human Resource Management and presently working on his dissertation for the degree of Doctor of Business Administration.

Dr. Mendoza as an HR and Management consultant was formerly the Coordinator of MBA (Organizational Development and Hotel and Management) programs of the St. Paul University Manila (St. Paul University System), Head of MBA at Jose Rizal University, College Dean of ABE and visiting professor/lecturer both in the graduate and undergraduate schools in the Philippines. He also served as resource speaker, panel discussant and participants in various seminars in the graduate and undergraduate programs.

He is now working at the University of Batangas as a Full-Time Faculty Researcher and Graduate School Professor.

\section{REFERENCES}

\section{Books:}

1. Abaloso, P A. (1991). Personnel Management: The Efficient Management Employees. Manila: Philippines

2. $\quad$ Andres, T. A. (1991).Human Resource Management Practices in the Philippine Setting. Manila: Philippines

3. $\quad$ Broto, Antonio S. (2006). Statistics Made Simple. Philippines: National Bookstore Inc.,

4. $\quad$ Certo, Samuel. (2000). Modern Management. Philippines: Prentice Hall

5. Cooper, Donald R. (2001). Business Research Methods. Philippines: McGraw-Hill Education.

6. Dessler, Gary. (2001). Human Resource Management. Singapore: Pearson Education Asia Pte. Ltd.,

7. $\quad$ Greenhaus, Jeffry H. (1987). Career Management. U.S.A.,

8. Hall, Calvin S. (1998). Theories of Personality. U.S.A.: John Wiley and Sons Inc.,

9. Henslin, James. (1991). Down to Earth Sociology. New York.

10. Hodgetts, R. M. (2002). Modern Human Relation's at Work. South-Western: USA,

11. Holland, John. (1973). Making Vocational Choices: A Theory of Careers. U.S.A.,

12. Josefowitz, Natasha, Ph.D. (1995). People Management. Philippines.

13. Kaila, H.L., Ph.D. (2003). Organizational Behavior and HRM. Delhi: Virender Kumar Arya,

14. Kossek, E. E. and Block, R. N. (2000). Managing Human Resources in the @ $1^{\text {st }}$ Century (from core concepts to strategic choice). South-Western College Publishing: USA,

15. Macionis, John. (2002). Sociology. Singapore: Pearson Education Asia Pte. Ltd.,

16. Maquiso, Teresita R., Ph.D. (1997). Socio-Anthro: An Introduction to Social Sciences. Philippines.

17. Martires, C. R. and Fule, G. S. (1993). Management of Human Behavior in Organizations. National Bookstore: Philippines.

18. McShane, Steven L. et.al. (2005). Organizational Behavior: Emerging Realities for the Workplace Revolution. Philippines.

19. Mikhailov, Feliks. (1980). The Riddle of the Self. U.S.A. 
20. Moorhead, Gregory. (1998). Organizational Behavior: Managing People and Organizations. New York: Houghton Mifflin Company.

21. Newstrom, John W. (2007). Organizational Behavior: Human Behavior at Work. New York: McGraw-Hill Companies, Inc.,

22. Noble, Sara P. (1997). Managing People Successfully: 47 Proven Ideas. Delhi: Global Business Press.

23. Panopio, Isabel S. (2003). Society and Culture: Introduction to Sociology and Anthropology. Philippines,

24. Schaefer, Richard T. (2005). Sociology: International Edition. Philippines: McGraw-Hill Education.

25. Sevilla, Consuelo G. Ed.D (1998). General Psychology with Values Development Lessons. Philippines.

26. Sison, P. S. (1985). Employee Training and Development. National Bookstore: Philippines.

27. Young, F. C. (2006). Organizational Development Made Easy. Philippines: Aviba Publishing House Inc.

28. Young, F. C. (2003). Statistics Made Easy. The B Series: Philippines.

\section{Articles/Journals:}

1. Adopted from Kirk, J. J. J., Downey, D., Duckett, S., and Woody, C., Name Your Career Development Intervention. http://education.uncc.edu/jageretes/61013\%20Case\%20Studies\%20F01. Date retrieved: November, 2006

2. Andres, T. Q. (1885). "How Social and Moral Values Influence Work Attitudes, and Homelife". Manila: Philippines

3. $\quad$ Arellano, K. (1999). Work vs. Family._Denver Business Journal, 50(46), 19a-20a.

4. Belk, J. (1999). Employment firms moving to provide clients one-stop-shop. San Antonio Business Journal, 13(12), 17-18.

5. Bernes, K. and Magnusson, K. (1996). A description of career development services within Canadian organizations. Journal of Counseling and Development, 76(6), 569-575.

6. Brown, B. (1998). Part-time work and other flexible options. (ERIC Digest No. 192). Columbus, OH: ERIC Clearinghouse on Adult, Career, and Vocational Education.

7. $\quad$ Caplan, W. (1997). Plight of high-tech execs: Should I be a manager? Boston Business Journal, 17(24), 910.

8. Cheraskin, L. and Campion, M. (1996). Study clarifies job-rotation benefits. Personal Journal, 75(11), 3136.

9. Duff, S. (1999). Poll: More plan sponsors tapping phased retirement approach. Employee Benefit News, 13(8), 50-51.

10. Health risks of retirement. (1997). Worklife Report, 10(3), 2-3.

11. Hogan, J. (1998). Helping employees to grow key to a company's vitality. Kansas City Business Journal, 16(52), 25-26.

12. Howell, J. (1999). O sweet sabbatical. Wenatchee Business Journal, 13(5), b8-b9.

13. Hudson, F. (1997). Career plateau transitions in midlife, and how to mange them [62 paragraphs]. In career Transitions in Turbulent Times. 257-266. [Online]. Greensboro, NC: ERIC Clearinghouse on Counseling and Student Services. Available: http://icdl.uncg.edu/ft/051199-09.html [September 26, 1999].

14. Jackson, S. E. and Schuler, (1990). “American Psychologist. Human Resources Planning".

15. Jansen, B. T. (1989). Training and Development Journal, Madison, Wisconsin". American Society for Training and Development, Volume 3.

16. Jonson, C. (1997). Multiple career paths help retain talent. HR Magazine, 42(10), 59-64.

17. Kanouse, D. (1999). Make temporary assignments work. Federal Times, 35(6), 16-20.

18. Lawer, E. E. III (1988). "Choosing an Involvement Strategy". Academy of Management Executive.

19. Nelson, F. (1999). Career coaches busy as more switch jobs. Denver Business Journal, 50(49), 15-16.

20. Parker, S. K. (1998). Enhancing role breadth self-efficacy: The roles of job enrichment and other organizational interventions. Journal of Applied Psychology. 83(6), 835-852.

21. Rhodes, A. (1995). Follow your heart. American Fitness, 13(6), 48-52.

22. Semas, J. (1997). Taking off from the hi-tech grind. HR Magazine. 42(9), 122-128.

23. Sideways bound: Success doesn't always flow up. (1996). Managing Office Technology, 41(11), 25-30.

24. Solomon, C. (1995). Navigating your search for global talent. Personnel Journal, 74(5), 94-99.

25. Terrel, P. (1997). Employee cross training initiatives. http://www.home.istar.ca/-p_terrel/cross.htm. [September 30, 1999] 
26. Tucker, R. and Moravec, M. (1996). Dual career path plan rapidly gaining favor. Washington Business Journal, 14(47), 26-27.

27. Whittington, J. (1998). The same motivational style cannot be used for all employees. Business Press, 10(50), 27-28.

\section{Published and Unpublished Thesis and Dissertation:}

1. Abaloso, P. A. (DBA Dissertation). Human Resource Management Practices of Selected Top Corporations in the Philippines. PUP, Manila: 1985

2. Arce, R. V. (Unpublished Thesis). Job Attitudes and Behavior in Metro Manila Factory.

3. Rizal Technological Colleges. Mandaluyong City: 1986

4. Cabigao, R. E. (Unpublished Thesis). Job Performance and Job Satisfaction of Nursing Staff of the Philippines Heart Center of Asia. University of the East Manila, Philippines: 1989

5. Magno-Miguel, A. D. Organizational Climate, Job Performance, and Job Satisfaction of the Ministry of Education, Culture and Sports. Rizal Technological Colleges. Mandaluyong City: 1986

6. Mendoza, C. N. (Published Dissertation). Human Resource Management Practices and Their Effects to Faculty Performance in Selected Private Tertiary Educational Institutions in Metro Manila.

7. Technological University of the Philippines. Manila, Philippines: 2003

8. Uchida, R. B. (Unpublished Collegiate Thesis). Factors Affecting Career Path Choices of Tertiary Students in [Select] Educational Institutions in Metro Manila. Southvilee International School and Colleges. Las Pinas City: 2006

\section{Electronic Sources:}

1. B.J. Gupita, www.quoteworld.org, Date retrieved: October, 2006

2. Career, Members.aol.com/hgsthesis/glossary.htm, Date retrieved: October, 2006

3. Career Path, Wordnet.princeton.edu, Date retrieved: July, 2006 Career Plateau Transitions In Turbulent Times.

4. Career Plateau Transitions in Midlife and How to Manage Them Hudson, F. (1997), A Model of Worklife Transitions, Schlossberg, N. (1997), http://icdl.uncg.edu/051199-09.html

5. Change Agent, www.vmec.org, Date retrieved: July, 2006

6. Employee Cross Training Initiatives, Terrel, P (1997), http://www.home.istar.ca/-p terrel/cross.htm

7. Name Your Career Development Intervention, Kirk,J.J., Downey, D., Ducket, S. and Woody, C., http://education.uncc.edu/jagretes/61013\%20Case\%20Studies\%20F01. Date retrieved: Novemer, 2006

8. Organization, www.bizmanuals.com, Date retrieved: July, 2006

9. Philippine Economic Data, www.pacificbridge.com, Date retrieved: September, 2006

10. Statistical Information, www.freeessays.cc, Date retrieved: September, 2006

11. Strategic Partnership, www.glencoe.com, Date retrieved: October, 2006

12. World Economic Data, www.indexmundi.com, Date retrieved: October, 2006 
NOTES 